\author{
УДК 81'23 ～DOI: $10.30982 / 2077-5911-2018-35-1-84-98$ \\ ЗАСТОЛЬНЫЕ БЛАГОПОЖЕЛАНИЯ \\ В КОНТЕКСТЕ ЭТНОКУЛЬТУРНОЙ СТЕРЕОТИПИЗАЦИИ \\ СОЦИАЛЬНО-ПРОФЕССИОНАЛЬНОЙ СРЕДЫ \\ ВОЕННОСЛУЖАЩИХ США
}

\author{
Романов Александр Сергеевич, \\ к.ф.н., докторант 32 кафедры английского языка (основного) \\ Военного университета МО РФ \\ ул. Волочаевская, д. 3/4, г. Москва, Россия, 111033 \\ biyalka@mail.ru
}

Выбор ракурсапредлагаемого вниманию читателя исследования определяется характером взаимоотношений между феноменами «этнос», «культура», «язык». В качестве объекта научных изысканий выступают распространенные в массовом языковом сознании носителей американской лингвокультуры стереотипные представления о социальном институте вооруженных сил, аксиологических доминантах армейской субкультуры, а также речевом портрете референтного образа военнослужащего армии США. Предметом научного исследования избран армейский тост как продуктивное языковое средство экспликации этнических стереотипов армейской субкультуры. Важнейшим элементом концептуальной картины мира социально-профессиональной группы военнослужащих выступает стереотип, неразрывно связанный с духовным наследием американской лингвокультуры.

Тосты GI, выступающие неотъемлемой частью палитры армейского идиома и наделенные функцией аксиологической ретрансляции, способствуют порождению и закреплению стереотипов коллективного сознания. Застольные благопожелания отражают духовные начала армейской субкультурной традиции, морально-этические нормы, правила вербального и невербального поведения военнослужащих. Совокупность воплощенных в знаках языка артефактов армейской культуры, к числу которых, очевидно, принадлежат и военные тосты, отражает ключевые ценности воинской среды, позволяет верно ориентироваться в критических ситуациях и принимать оптимальные решения. Эпидейктический жанр тоста, таким образом, может быть охарактеризован как стереотипогенное языковое средство манифестации ценностей армейской субкультуры, ее корпоративной этики.

Ключевые слова: ВС США, армейская субкультура, стереотипизация, стереотип, языковые средства экспликации этнических стереотипов, армейский тост

Переход на антропоцентрическую парадигму исследования, сопряженный с переключением внимания лингвистов на речевую деятельность человека в совокупности с ее экстралингвистическим контекстом, а также актуализация коммуникативно-прагматического аспекта изучения языка привели к тому, что феномены, ранее находившиеся на периферии лингвистической науки, все чаще становятся объектом научного внимания. К числу 
Романов А.С. Застольные благопожелания в контексте этнокультурной...

подобных феноменов принадлежит тост как эпидейктический прагматически маркированный жанр застольного этикета. Тосты относятся к древним формулам речевой культуры, обнаруживают функциональную активность, культивируются и адаптируются к современному дискурсивному пространству. В настоящем исследовании предпринята попытка выявления аксиологических доминант армейской субкультурной среды США, специфически эксплицированных в армейских тостах. Объектом научных изысканий избраны бытующие в массовом сознании обывателя американской лингвокультурной общности устойчивые во времени стереотипизированные репрезентации имиджа ВС США, а также облика референтного носителя армейской субкультуры. Отметим, что важнейшим элементом концептуальной картины мира социально-профессиональной группы военнослужащих выступает стереотип, неразрывно связанный с духовным наследием американской лингвокультуры. Предметом настоящего исследования выступает эпидейктический жанр тоста как языковое средство репрезентации ценностных доминант армейского социокультурного пространства и речевой механизм экспликации упрощенных представлений о социальном институте вооруженных сил. Целью настоящего исследования ставится дальнейшее осмысление природы социально-психологического феномена стереотипизации применительно к социально-профессиональной среде военнослужащих США. Нами выдвигается тезис, сообразно которому устойчивые речевые формулы армейского застольного этикета обнаруживают свойство стереотипогенности.

В лексикографических источниках тост (англ. toast) традиционно интерпретируется как застольное пожелание, предложение выпить вина в честь кого-нибудь или чего-нибудь, здравица [СРЯ 1984: 389].

«Полный словарь лингвистических терминов» под редакцией Т.В. Матвеевой определяет тост как эпидейктический жанр социально-бытового красноречия. Под последним понимается речевое мастерство в бытовой сфере, способствующее культурному обогащению повседневного речевого общения, установлению и культивированию таких его форм, в которых отражаются национальные традиции, ценности духа и здоровый гедонизм бытия. Социальнобытовое красноречие реализуется в монологических (похвальная речь и ее варианты: приветственная и юбилейная речь, а также прощальная речь - надгробное слово; разговорный рассказ, застольная речь и тост) и диалогических жанрах (разговорная беседа, спор, болтовня) [Матвеева 2010: 446]. Прагматическая интенция пафоса торжественных речей, утверждал Аристотель, может быть разной: хвалить или порицать [Аристотель 2000: 8]. Социально-бытовое красноречие отражает намерение устанавливать и поддерживать добрые отношения между людьми, воздавать почести достойным, поддерживать и ободрять нуждающихся в этом, утверждать оптимизм, способствовать полезному и приятному времяпрепровождению в неформальной обстановке. Иными словами, задачи логические в социально-бытовом красноречии уступают место этическим и эстетическим интенциям адресанта [Матвеева 2010: 446]. Под тостом понимается малый жанр бытового красноречия, застольная заздравная эпидейктическая речь. Для тоста характерна оптимистическая тональность, в основе которой лежит идея похвалы. Назначение тоста сводится к тому, чтобы говорить обо всем хорошем в связи с данной конкретной ситуацией.

Вопросы психолингвистики 1 (35) 2018 


\section{Теоретические и экспериментальные исследования}

Тост может представлять собой развернутую прямую похвалу с обязательной заключительной речевой формулой приглашения поднять бокалы за кого-либо или что-либо. Неожиданный семантический поворот в конце тоста производит сильное прагматическое воздействие на адресата: через эмоции доставляет эстетическое удовольствие участникам застолья. Именно поэтому в тосте ценится эффект неожиданности. Владение жанром тоста предполагает не только правильное составление его текстов, но и умелое преподнесение, а также знание культуры застольного поведения в целом [Там же: 494].

Назначение эпидейктической речи состоит в обращении к эмоциональной сфере, сплочении аудитории, создании благоприятной коммуникативной атмосферы. Информирующая и персуазивная интенции говорящего выступают в качестве вспомогательных. Аргументация тоста носит риторический характер. Речи, призванные вызывать положительные эмоции, возвышенные чувства, могут быть произнесены в таких жанрах, как поздравление, благодарность, напутствие, прощание, приветствие, тост. Одни и те же жанры могут быть выбраны как в официальной, так и неофициальной сферах общения. В риторических речах запечатлены знаменательные события социальной практики и факты, вызывающие сильный эмоциональный отклик. На этапе элокуции существенным достоинством речи выступает ее образность, оригинальность, уход от речевых стандартов, шаблонов (как, например, пожелание крепкого здоровья, творческих успехов и счастья в личной жизни). Использование изобразительно-выразительных средств является важнымусловиемусиления воздействующегоэффектаречи. Классификация публичных выступлений представлена официальнымм, неофициальным и бытовым контекстами коммуникации [Меньшенина 2005: 182-183].

Тост принадлежит дискурсивному пространству риторики. Уходящий своими корнями в глубь античности эпидейктический жанр речи был впервые описан Аристотелем, хотя создание торжественного жанра приписывается Горгию из Леонтии [Шаталова 2009: 10-11]. Обращенная к внеязыковой действительности эпидейктическая речь дает представление о морали и антиморали. Ритуал и правила речевого этикета составляют основу эпидейктики. Эпидейктический жанр истолковывается как «устойчивая форма реализации речевого намерения адресанта, ориентированная на конкретного адресата; как единство свойств формы и содержания (композиции и стиля), определяемое целью и условиями социальнобытового или социально значимого общения <...>» [Там же: 5]. В качестве предмета речи могут выступать добродетели, пороки, знаменательные исторические события или даты, выдающиеся личности, памятные страницы социального опыта. Эпидейктическая речь представлена двумя разновидностями: официальной и бытовой. Официальная эпидейктика включает торжественную, юбилейную, благодарственную, приветственную, нобелевскую, застольную и надгробную (соболезнование) разновидности речи, тост, комплимент, инаугурационную речь, напутствие, похвалу, порицание. Бытовая эпидейктика представлена такими жанрами, как поздравление, благодарность, соболезнование, тост, комплимент, похвала, хула, обвинение, осуждение. В отличие от официальной, бытовая эпидейктика предполагает личностность речи, некоторую интимность, большую свободу в выборе средств выразительности [Там же: 12-13]. Эпидейктический 
Романов А.С. Застольные благопожелания в контексте этнокультурной...

дискурс характеризуется такими жанровыми признаками, как повод, торжественная обстановка, фон произнесения, соблюдение системы ролей, наличие четкой структуры, преобладание книжного строя речи, употребление изобразительноэкспрессивных средств языка. Тост, апеллирующий к эмоциональной сфере, принадлежит к малым формам хвалебной речи [Там же: 4].

Тост - это и дискурсивное событие, рассматриваемое в совокупности с экстралингвистическими факторами в конкретной коммуникативной ситуации. Под речевым, или дискурсивным, понимается событие, обнаруживающее общность цели, темы, тона, стиля и обстоятельств общения. Участники дискурсивного события следуют общему для всех своду правил коммуникативного взаимодействия. Тосты могут быть классифицированы следующим образом: по теме (свадебные, поздравительные, поминальные и т.д.), по форме предъявления (тосты в стихах или в прозе), по наличию/отсутствию в основе преиедентного текста (анекдотов, пословиц и поговорок, афоризмов, притчей и т.д.), по характеристике адресата $u$ отправителя (тосты, обращенные к конкретному адресату или целевой аудитории, а также тосты, произнесенные от первого лица и от группы/коллектива людей), по характеру коммуникативной ситуации [Мощанская, Савчук 2011: 80-83].

Понятие прецедентного текста было введено в научный обиход Ю.Н. Карауловым. Под прецедентными понимаются когнитивно и эмоционально значимые тексты, хорошо известные широкому кругу лиц, «обращение к которым возобновляется в дискурсе данной языковой личности» [Караулов 1986: 105]. Прецедентный текст интерпретируется как последовательность знаковых единиц, обладающих цельностью, связностью и ценностной релевантностью для данной культурной общности. Прецедентный текст, варьируемый от пословицы или афоризма до эпоса, наряду с вербальным может включать визуальный компонент (плакат, комикс, фильм, видеоряд). «Частые отсылки к тексту в процессе построения новых текстов в виде реминисценций есть показатели ценностного отношения к данному тексту и, следовательно, его прецедентности» [Слышкин 2000: 28-29]. Обладающий экспрессивной составляющей тост направлен на установление и поддержание контакта с целевой аудиторией (реализация фатической функции), создание, в зависимости от прагматической интенции говорящего, определенного эмоционального фона. Композиционное своеобразие прозаической формы предъявления тоста включает обращение, обозначение повода мероприятия, характеристику объекта благопожелания или коммуникативной ситуации, завершаемые благопожеланием или поздравлением. Тост традиционно заканчивается призывом осушить бокалы. Наличие прецедентного текста и композиционная структура тоста носят вариативный характер. К инвариантам композиции тоста относятся обращение, называние повода произнесения речи, а также призыв поднять и осушить бокалы [Мощанская, Савчук 2011: 82]. Тост характеризуется широким употреблением фигур речи и тропов, придающих тексту живость образов.

Автор статьи «Toasting the Armed Forces» R. Morris пишет о том, что тосты имеют давнюю традицию, восходящую к эпохе Средневековья. Современная манера произнесения благопожеланий сохранила английские каноны публичных выступлений XVIв. Во время повседневных совместных приемов 
пищи и официальных церемониальных обедов армейские тосты служат вербально реализованным знаком пиетета и лояльности к государству, символом почитания воинских традиций. Естественным спутником застольных благопожеланий в армейской, как, впрочем, и любой другой среде, выступает винопитие. Если же военнослужащийнеупотребляетспиртныхнапитков, тоданьуваженияксобравшимся по определенному поводу может быть выражена символическим поднятием бокала с вином или водой либо поднесением бокала ко рту в знак солидарности с воинским коллективом. Отметим, что отказ от участия в застолье может быть встречен неодобрением и критикой со стороны сослуживцев. Подтверждением сказанному послужит юмористическое изречение, позаимствованное нами из морского фольклора ВС США: a toast with water will die by drowning 'тост утрачивает всякий смысл в том случае, если бокал наполнен водой' [Morris 2014].

В пособии «Dining-In and Dining-Out Handbook», разработанном штабом Командования комплектования личного состава ВС США, приводится следующее. Предположительно, практика совместной трапезы не была характерной для воинских подразделений средневековой Англии, однако была типичной для представителей монашеского ордена и образовательных заведений - университетов. Этикетный обычай произнесения тостов обрел силу после учреждения первых офицерских столовых, созданных по инициативе британского истеблишмента. Первая и Вторая мировые войны способствовали культурному обмену между британской и американской армиями, внесли заметную лепту в процесс заимствования и культивирования американцами эпидейктических традиций бытового красноречия [USAREC Pamphlet 600-15 1994: 1]. Как правило, официальные армейские тосты адресованы президенту США, определенному виду, роду войск или же конкретному воинскому подразделению. Ср.: Speaker: "Fellow Officers, I propose a toast to the Commander-in-Chief, the President of the United States." I Response: "To the President."; Speaker: "To the President of the United States" /Response: "To the President"; Speaker: "To the United States Army" / Response: "To the Army." Примечательно, что армейские тосты поднимаются за организацию или ведомство, но никогда не обращены к частному лицу (исключение, пожалуй, составляют тосты, адресованные президенту). Согласно традиции, во время неофициальных застолий назначается так называемый «орудийный расчет» (gunners) в составе одного человека (как правило, это младший по званию военнослужащий), в обязанности которого вменяется своевременное наполнение бокалов собравшихся на протяжении всего мероприятия. Во время официальных празднований эта неформальная традиция неуместна [Там же: 5].

В руководстве «Guide to the Military Dining-in», разработанном в Военной академии West Point (шт. Нью-Йорк), находим: “Toasting is the ancient tradition of drinking together in honor of someone or some group, in order to show respect or appreciation. It is believed that this custom came into wide acceptance after the effects of poisons were discovered. When two persons, who might be antagonists, drank from the same source at the same instant and suffered no ill effects, a degree of mutual trust or rapport was established. Today, toasting is a gesture to honor the person or group being recognized. It is not necessary to drain the glass, or even to sip the wine; a mere touch of the glass to the lips satisfies the ceremony [Guide to the Military Dining-in 1999: 8]. 
Романов А.С. Застольные благопожелания в контексте этнокультурной...

Сложная система регулирования в значительной степени формализованного поведения (вербального и невербального), а также сложившиеся стереотипы армейского субкультурного универсума играют значимую роль в повседневном укладе жизни военнослужащих армии США. Совокупность воплощенных в знаках языка артефактов армейской культуры, к числу которых, очевидно, принадлежат и военные тосты, отражает ключевые ценности воинской среды, позволяет верно ориентироваться в критических ситуациях и принимать оптимальные решения. Эпидейктический жанр тоста, таким образом, может быть охарактеризован как стереотипогенное языковое средство манифестации ценностей армейской субкультуры, ее корпоративной этики. Вербальная циркуляция аксиологически маркированных памятников культуры коллективного сознания военнослужащих способствует снижению негативного воздействия стрессогенных факторов, благотворно сказывается на моральном климате воинского коллектива.

Следуя логике изложения материала, далее мы предлагаем остановиться на критериях дифференциации застольных текстов эпидейктического жанра, a также подвергнуть лингвокультурологическому осмыслению специфически эксплицированные в армейских тостах стереотипные представления социальнопрофессиональной среды военнослужащих. Полагаем, что армейские тосты могут быть классифицированы следующим образом: по характеру коммуникативной ситуации выделяют официальные и социально-бытовые mосты; по форме репрезентации - тосты в стихах или в прозе; по характеру прагматической интенции адресанта можно выделить поздравительные, хвалебные, порицающцие, юмористические и др. разновидности тоста; по наличию реминисцентных текстов (ФЕ, единиц социально-группового диалекта, воинских девизов, фрагментов строевых песен и т.д.) различают прецедентные и непрецедентные тосты.

Традиционно официальные армейские тосты адресованы главе государства, вооруженным силам и связаны с непреходящими ценностями армейской субкультуры и общечеловеческими ценностями. Приведем примеры официальных тостов социально-профессиональной среды военнослужащих: "Here's to American valor, / May no war require it, but may it ever be ready for every foe." - «За американскую доблесть, / Пусть не будет войн, чтобы испытать ее на прочность, но пусть американская отвага будет всегда наготове для всякого противника»; "Here's to the Army and Navy, / And the battles they have won, / Here's to America's colors / -The colors that never run.” - «За армию и флот, / И победы, одержанные ими, / За американский флаг / - Флаг, не ведающий поражения»; "Here's to the land we love and the love we land." - «За землю, которую мы любим и любовь, которую мы обретаем»; "May we love peace enough to fight for it". - «Пусть наша любовь к миру будет достаточно сильна для того, чтобы сражаться за него»; “To absent friends." - За тех, кого с нами нет [Morris 2014], [https://www. etiquettescholar.com].

К категории официальных могут быть отнесены тосты, приуроченные к завершению срока службы военнослужащего с последующим выходом в отставку; а также траурные застольные речи, посвященные памяти павших в бою воинов. Обратимся к примерам. "A toast to one / Whose service has guaranteed / Our freedom to celebrate today. / A toast to John / Who has served so 
that we / May live as we wish / In this land of the free. / Today we honor John and salute his service. / May we always remember that serving one's country / Is the ultimate expression of love / For family, friends and neighbors. - «Поднимаю тост за того, / Чья служба стала гарантом нашей свободы сегодня. / Тост за Джона, / Который служил для того, чтобы мы / Могли жить так, как мы того желаем / В этой стране свободных людей. / Сегодня мы чествуем Джона и отдаем дань уважения его службе. / Давайте не будем забывать о том, что служба Отечеству / Является наивысшим проявлением любви / К семье, друзьям и соседям» [http://www.militaryservicecompany.com].

"To those who were vigilant so we could rest, / Who gave ererything that we might thrive, / Who are silent that we may breethe free, / We honour you." - «За тех, кто не смыкал глаз, охраняя наш сон, / Кто отдал все во имя нашего процветания, / Кто умолк навеки ради того, чтоб мы могли дышать свободно, / Мы чтим вашу память» [The Marine Corps Gasette 2016: 3].

Семантическое ядро вышеприведенных армейских тостов, пронизанных духом самоотречения ради всеобщего национального процветания, может быть интерпретировано следующим образом: военная служба - величайшая честь и наивысшая форма проявления любви к Отечеству. В данном контексте представляется уместным обратиться к официальному девизу ВС США “This we'll defend” - «На страже свободы США», имплицитный посыл которого зиждется на идее о том, что военные призваны защищать свободу и американский образ жизни, выступающие ключевыми ценностными категориями американской лингвокультурной общности [Odierno 2012].

Обратимся к иллюстративному материалу армейских тостов, посвященных видам и родам войск ВС США.

\section{Сухопутные войска}

“Here's to the bravest sons of guns!” - «За отважнейших из сыновей войны». "Put your trust in God, boys, but keep your powder dry." - «Уповайте на Бога, ребята, но порох держите сухим» (на Бога надейся, а сам не плошай) [Morris 2014], [https://www. etiquettescholar.com]. Характерной особенностью тоста, традиционно произносимого в честь $\mathrm{CB}$, выступает наличие прецедентных фрагментов, представленных устойчивыми словосочетаниями to keep one's powder dry - досл. держать порох сухим, быть готовым во всеоружии; и to trust in God - веровать в Бога. Согласно лексикографическому источнику American Heritage Dictionary of Idioms, под ФЕ to keep one's powder dry, авторство которой приписывается вождю английской буржуазной революции XVII в. Оливеру Кромвелю (1599-1658 гг.), понимается следующие: "this colloquial expression, which originally alluded to keeping gunpowder dry so that it would ignite, has been used figuratively since the 1800s but today is less common than TAKE CARE” [Ammer 1992: 578]. Здесь мы бы хотели провести параллель между прецедентным текстовым фрагментом to trust in God и национальным девизом США in God We Trust - «мы верим в Господа». Отметим также, что позаимствованная из текста воинской присяги Oath of Enlistment фраза So help me God - и да поможет мне Господь; взывает к религиозным чувствам военнослужащих и укрепляет веру в незыблемость духовного начала армейской субкультуры [http://www.army.mil/ values/oath.html]. «< ..> Наиболее вдохновляющей общей целью армии может быть сознание того, что она является божественным инструментом и призвана творить 
Романов А.С. Застольные благопожелания в контексте этнокультурной...

суд божий. Ибо какая человеческая сила может противостоять божественной? Моральный дух подразделения и части можно поднять до высокого уровня только тогда, когда солдаты вдохновляются высокими и бескорыстными идеалами» [Коупленд 1991: 56-57].

"The girl and boy are bound by a kiss / But there's never a bond, old friend like this:/ We have drunk from the same canteen”"(General Charles G. Halpine).- “Девушка и юноша связаны узами поцелуя / Но наши узы, старый друг, прочнее остальных: / Мы испили из одной фляжки” (генерал Ч. Дж. Халпайн) [https://www.etiquettescholar.com]. Яркий метафорический образ ФЕ to drink from the same canteen «пройти огонь, воду и медные трубы» наделен глубоким символическим содержанием, указывающим на существование подлинно духовной, родственной связи между сослуживцами, опаленными пламенем войны и прошедшими все испытания вместе, плечом к плечу. Изречение to drink from the same canteen выступает семантическим ядром тоста, эксплицирующим стереотип о братских взаимоотношениях, объединяющих военнослужащих. Подтверждением сказанному послужит цитата из книги C.G. Samito Becoming American under fire: Irish Americans, African Americans and the politics of citizenship during the Civil War Era: " $<\ldots$.. soldiers did so (would share the same canteen - прим. наше, A.P.) in the communion of military service - the sharing of hard marches and empty stomacks, the excitement of battles and the doldrums of camp life and crawling to a wounded soldiers on the battlefield to give him a drink" [Samito 2009: 113].

\section{Военно-морские силы и Корпус морской пехоты}

"Here's to the Navy - true hearts and sound bottoms." - «За ВМC - преданные сердца и прочные суда».

"I give you muscles of steel, nerves of iron, tongues of silver, hearts of gold, necks of leather - the marines.” - «Вверяю вам стальные мускулы, железные нервы, красноречивые уста, добрые сердца и бритые затылки - морских пехотинцев!» [https://www.etiquettescholar.com].

\section{Военно-воздушные силы}

"They've got wings, but they're not always angels. Here's to our Air Force."«У них есть крылья, но они не всегда ангелы. За наши ВВС» [Morris 2014].

"We toast to our hearty comrades who have fallen from the skies, I And were gently caught by God's own hands to be with him on high, / To dwell among the soaring clouds they have known so well before, / From victory roll to tail chase, at heaven's very door. I And as we fly among them, we're sure to hear their plea, I Take care, my friend, watch your six, and do one more roll for me."- «Мы поднимаем тост в честь дорогих товарищей, павших с небес, / И бережно подхваченных руками Господа с тем, чтобы разделить Его небесную обитель, / Чтоб жить среди парящих облаков, так хорошо знакомых им, / От победного виража до захода в хвост противнику у самых райских врат. / И поскольку мы летаем среди них, до нас доносятся мольбы наших товарищей: «Будь осторожен, друг мой, будь начеку и сделай еще одну “бочку” для меня» [http://www.militarywives.com].

Социально-бытовые тосты, произносимые в неформальной обстановке, зачастую не лишены юмористического содержания:

«May your glass be ever full. / May the roof over your head be always strong.

Вопросы психолингвистики 1 (35) 2018 


\section{Теоретические и экспериментальные исследования}

/ And may you be in heaven / half an hour before the devil knows you're dead.» - «Пусть будет кубок полон твой всегда. / Пусть кров твой будет прочен вечно. / Пусть ты окажешься в раю / За полчаса до того, как дьявол получит известие о твоей смерти».

"Here's health to you and to our corps, / Which we are proud to serve: I In many a strife we have fought for life/And never lost our nerve. /If the Army and the Navy/ Ever look on heaven's scenes, / They will find the streets are guarded By the United States Marines. - «За ваше здоровье и наш Корпус, / В котором мы имеем честь служить: / Во многих боях мы сражались не на жизнь, а на смерть / И никогда не теряли самообладания. / И если армия и флот / Когда-нибудь окинут взором небеса, / То обнаружат, что улицы в раю охраняются / Морскими пехотинцами США».

"To the sailor - the only person I know who gets sea sick taking a bath." «За моряка - единственного известного мне человека, страдающего морской болезнью в ванной».

"To the wisdom of sailors. As Sir Walter Scott said, "Tell it to the marines the sailors won't believe it." - «За мудрость моряков. Как говаривал сэр Вальтер Скотт, «расскажите это морской пехоте, моряки в это не поверят» [https://www. etiquettescholar.com]. Благодаря ФЕ tell it to the marines «рассказывать небылицы, говорить вздор» в тосте в эксплицитной форме вербализован распространенный стереотип об интеллектуальной ограниченности представителей Корпуса морской пехоты. "This term originated among British sailors, who regarded marines as naive and gullible" [Ammer 1997: 1055]. Датируемое началом ХІХв. изречение tell it to the marines выражает крайнюю степень недоверия к сказанному, скепсис. Другими зафиксированными в солдатском фольклоре примерами, подкрепляющими тезис о граничащей с глупостью наивности морских пехотинцев, послужат шутливые аббревиатуры: MARINES = Muscles Are Required Intelligence Not Essential - cp. pyc. «сила есть - ума не надо» и MARINE = Math And Reading Is Not Essential - «умение считать и писать для морской пехоты не обязательно [Романов 2015: 155] [http: // www.vetfriends.com, http://www.supertrap.com].

"Here's to the ships of our Navy, / And the ladies of our land; / May the first be ever well rigged, / And the latter ever well manned." - «За боевые корабли нашего флота / И наших женщин; / Пусть первые будут всегда хорошо оснащены, / А последние никогда не познают одиночества».

С лингвистической точки зрения эпидейктический жанр застольных благопожеланий характеризуется специфичной структурной организацией и лексическим наполнением. Тост отличается совокупностью лексикосемантических, грамматических и стилистических особенностей.

Лексико-семантические особенности. Наиболее употребительную в языке тостов лексику можно разбить на ряд семантических групп. Религиозно-обрядовая лексика: God, plea, loss, angel, faith/trust, heaven, haven's door, haven's scenes, skies, devil. Лексика, взывающая к патриотическим чувствам военнослужащих и этосу референтного облика GI: country, America's colors, military service, patriotism, patriot, loyalty, good, evil, valor, courage, glory, pride, foe, the unfair. Социальнобытовая лексика: community, brotherhood, family, brother, comrade, fallen comrade, hearty friend, absent friend. Лексика, выражающая абстрактные категории: peace, 
Романов А.С. Застольные благопожелания в контексте этнокультурной...

life, freedom, love, health, memory, demise/death, war.

Грамматические особенности. Структурно тост может быть разделен на ядро - toast message и элементы обрамления - toast frame. В отличие от вариативного ядра элементы обрамления - относительно устойчивая, стандартная часть тоста. В застольных речах частотны устойчивые речевые формулы или стандартные речения: to... / here's to... / I propose a toast to... / I raise my glass to... Стандартной является вокативно-ответная структура армейского тоста - toast-response structure. Cp.: Toast: Here's to the US Army Commander-in-Chief / Response: Hear, hear!; Toast: "To the Flag of the United States of America" / Response: "To the Colors". В качестве ответа на тост может прозвучать выражение hear, hear! - поддерживаем, согласны! [http://www.militarywives.com]. Вошедшее в языковой обиход в конце XVIв. изречение представляет собой редуцированную речевую формулу, образованную от hear him!, выражающую чувство солидарности и одобрения речи докладчика. Этимологические истоки приведенного выражения восходят к парламентским прениям Соединенного Королевства Великобритании, в ходе которых запрещалось поддерживать выступление оратора овациями. Изречение hear him! стало своего рода компромиссом, назначение которого сводилось к привлечению внимания аудитории [Ammer 1997: 479].

Характерной особенностью армейского тоста выступает преимущественное употребление глаголов в оптативе с пожелательной семантикой (что с необходимостью проистекает из специфики тоста как благопожелания). Пожелательное наклонение в английском языке выражается с помощью модального глагола may: may your glass be ever full, may your roof be ever strong, may our ships be ever well rigged, may no war require American valor, but may it ever be ready for every foe.

Отличительным свойством тостов GI является широкое использование императивных конструкций: let's drink to..., put your trust in God, so help me God, keep your powder dry, take care, watch your six.

Традиционными для армейского тоста выступают апеллятивно-вокативные лексемы и словосочетания, обращенные к целевой аудитории: old friends, comrades, brothers-in-arms, dear veterans (vets).

Нередко в речевых произведениях застольных благопожеланий встречается и употребление соответствующих тематике прецедентных текстовых фрагментов: trust in God, but keep your powder dry - «на Бога надейся, а сам не плошай»; watch your six - «гляди в оба, будь начеку»; to have a heart of gold - «иметь доброе сердце», to drink from the same canteen - «вместе пройти через тяжелые испытания, пройти огонь и воду» (досл. испить из одной фляжки).

Эпидейктический жанр тоста также способен заключать элементы языковой игры на основе лексической полисемии: here's to the land we love and the love we land (в зависимости от морфологической принадлежности, лексема может иметь следующие толкования: land (n.) - земля, суша и land (v.) - приставать к берегу, причаливать, достигать (какого-то места)), may our ships be ever well rigged and may our women be ever well manned (инфинитивная форма глагола to man в данном контексте может быть интерпретирована следующим образом: 1. укомплектовывать личным составом, снабжать людьми и 2. обслуживать, управлять).

$$
\text { Вопросы психолингвистики } 1 \text { (35) } 201893
$$




\section{Теоретические и экспериментальные исследования}

Стилистические особенности. Частое употребление устойчивых словосочетаний, стандартных речений и формул, использование пословиц и поговорок, насыщенность языка армейских тостов религиозно-обрядовыми лексическими единицами, лексикой, выражающей моральные и абстрактные категории, а также ряд грамматических нюансов в совокупности формируют специфические особенности стиля языка тостов. Набор экспрессивноизобразительных средств армейских застольных текстов эпидейктического жанра представлен такими тропами, как эпитет, метафора, метонимия, сравнение, ирония и др. Проанализируем сказанное на примерах.

Эпитеты: tongues of silver - красноречивые уста, hearts of gold - золотые сердца, muscles of steel - стальные мышцы, necks of leather - бритые наголо затылки, nerves of iron - железные нервы, hearty comrades - дорогие товарищи, American valor- американская доблесть, fighter-model - образцовый солдат.

Метафоры и метонимии: sons of guns - сыновья войны; land of the free земля свободных людей; dwell among the soaring clouds - обитать среди парящих облаков; USAF pilots have got wings, but they're not always angels - у летчиков ВВС США есть крылья, но они не всегда ангелы; to drink from the same canteen - вместе пройти через тяжелые испытания.

Олицетворения: Uncle Sam - персонифицированный образ США, colors that never run- победоносный флаг (досл. флаг, который никогда не убегает).

Сравнения: pilots - angels, fighters - models, soldiers - guardians.

Эвфемизмы: absent friends/silent comrades/fallen soldiers - погибшие, павшие на поле боя; the unfair - противник.

Богатство материала тостов требует более детального описания и анализа застольного этикета военнослужащих. Здесь мы наметили лишь некоторые возможные аспекты его изучения. Очевидно, необходимо дальнейшее исследование данного феномена с точки зрения как собственно лингвистики, так и семиотики. Проведенное нами лингвокультурологическое исследование застольных эпидейктических текстов социально-профессиональной среды американских военнослужащих позволяет сделать следующие выводы:

- армейские тосты выступают продуктивным языковым средством экспликации этностереотипов речевой стихии военного коллектива;

- основу армейских тостов составляют такие аксиологические доминанты, как самоотверженное служение и верность Отечеству, патриотизм, мужество, сила духа, дух товарищества, сплоченность, дисциилинированность и др.;

- армейские тосты могут быть классифицированы следующим образом: по характеру коммуникативной ситуации выделяют официальные и социальнобытовые тосты; по форме репрезентации - тосты в стихах или в прозе; по характеру прагматической интенции адресанта - поздравительные, хвалебные, порицающие, юмористические и др. разновидности тоста; по наличию реминисцентных текстов (ФЕ, единиц социально-группового диалекта, воинских девизов, фрагментов строевых песен и т.д.) различают прецедентные и непрецедентные тосты.

- своеобразие армейских тостов представлено совокупностью лексических, грамматических и стилистических особенностей. 
Романов А.С. Застольные благопожелания в контексте этнокультурной...

\section{Литература}

Аристотель. Поэтика. Риторика. Спб.: Азбука, 2000. 347 с.

Ахманова О.С. Словарь лингвистических терминов. - М.: Советская энциклопедия, 1969. 608 с.

Караулов Ю.Н. Роль прецедентных текстов в структуре и функционировании языковой личности / Ю.Н. Караулов // Научные традиции и новые направления в преподавании русского языка и литературы. Доклады советской делегации на VI конгрессе МАПРЯЛ. - М.: Русский язык, 1986. С. 105-126.

Сльшикин Г.Г. Лингвокультурные концепты прецедентных текстов. - M., Academic, 2000. $141 \mathrm{c}$.

Меньшенина С.В. Жанры речей. Классификация эпидейктической речи / С.В. Меньшенина // Вестник Южно-Уральского государственного университета. Серия: Социально-гуманитарные науки. Выпуск № 7 (47). Челябинск: ЮУрГУ, 2005. C. $181-185$.

Мощанская Е.Ю., Савчук А.С. Тост как устно-речевой дискурс / Е.Ю. Мощанская, А.С. Савчук // Вестник Нижегородского государственного лингвистического университета им. Н.А. Добролюбова. Выпуск 16. - Нижний Новгород: ФГБОУ ВПО НГЛУ, 2011. С. 80-90.

Коупленд H. Психология и солдат / пер. с англ. А.Т. Сапронова и В.М. Катеринича. 2 изд. М.: Воениздат, 1991. 96 с.

Культура русской речи: энииклопедический словарь-справочник / под ред. Л.Ю. Иванова, А.П. Сковородникова, Е.Н. Ширяева и др. М.: Флинта; Наука, 2003. $840 \mathrm{c}$.

Матвеева Т.В. Полный словарь лингвистических терминов / Т.В. Матвеева. Ростов н/Д: Феникс, 2010. 562 с.

Романов А.С. Языковые средства экспликации этнических стереотипов в картине мира американских военнослужащих: дис. ... канд. филол. наук: 10.02.19 / А.С. Романов. М., 2015. 195 с.

Словарь русского языка: в 4-х m. / под ред. А. П. Евгеньевой. - М.: Русский язык, 1981. Т. 1. А-Й. 698 с.; 1984. Т. 4. С-Я. 794 с.

Шаталова С.В. Эпидейктические жанры речи: автореф. дис... канд. филол. наук. Ярославль, 2009. 24 с.

Ammer $C$. The American Heritage dictionary of idioms. $1^{\text {st }}$ ed. $/$ Christine Ammer. - Boston: Houghton Mifflin Harcourt, 1997. 1191p.

Army.mil.com. URL: http://www.army.mil/values/ (дата обращения: 21.06.17).

Dining-In and Dining-Out Handbook. USAREC Pamphlet 600-15. Headquarters United States Army Recruiting Command. - Kent.: Fort Knox, 1994. 9 p. URL: http://img. slate.com/media/53/military\%20dining\%20handbook.pdf (дата обращения 10.05.17).

Etiquettescholar.com. URL: https://www.etiquettescholar.com/dining_etiquette/ toasting_etiquette/toasts_for_all_occassions/military_toasts.html (дата обращения 12.05.17).

Guide to the Military Dining-in (revised 1999 edition). Cadet Hostess Office. Cullum Memorial Hall. - N.Y.: West Point, 1999. 26 p. URL: https://www.google.ru/url? $\mathrm{sa}=\mathrm{t} \& \mathrm{rct}=\mathrm{j} \& \mathrm{q}=\& \mathrm{esrc}=\mathrm{s} \&$ source $=$ web $\& \mathrm{~cd}=1 \& \mathrm{ved}=0$ ahUKEwiJlIX8s_VAhXDYJoKH 
fmDbIQFggmMAA\&url=http $\% 3 \mathrm{~A} \% 2 \mathrm{~F} \% 2 \mathrm{Fwww}$.usma.edu $\% 2 \mathrm{Fdca} \% 2 \mathrm{FSiteAssets} \% 2 \mathrm{~F}$ SitePages\%2FMilitary\%2520Dining\%2FMilitaryDiningInGuide.doc\&usg=AFQjCNFwijcpiRNDdVci8FqXCgMDug5nQ (дата обращения 12.08.17).

Militaryservicecompany.com. URL: http://www.militaryservicecompany.com/ military-tradition/toasting-armed-forces/ (дата обращения: 19.08.17).

Militarywives.com. URL: http://www.militarywives.com/index.php/protocolmainmenu-264/air-force-protocol-mainmenu-298/toasts-mainmenu-322 (дата обращения: 21.07.17).

Morris R. Toasting the Armed Forces / R. Morris. 2014. URL: http://www. militaryservicecompany.com/military-tradition/toasting-armed-forces/ (дата обращения: 13.08.17).

Odierno $R$. This We'll Defend / R. Odierno. 2012. - URL: http://armylive.dodlive.mil/index.php/2012/07/independence-day-2012/ (дата обращения 20.12.16).

Samito C.G. Becoming American under fire: Irish Americans, African Americans and the politics of citizenship during the Civil War Era / C.G. Samito. N.Y.: Cornell University Press, 2009. 320 p.

Vetfriends.com. URL: http: //www.vetfriends.com/jokes/index.cfm?startNum=50 (дата обращения: 14.03.13).

Supertrap.com. URL: http://www.supertrap.com/ST_Downloads_files/Army\%20 Slang.pdf (дата обращения: 15.11.13)

\title{
GI TOASTS WITHIN THE CONTEXT OF THE ETHNO-CULTURAL STEREOTYPIZATION OF THE US MILITARY SOCIO-PROFESSIONAL ENVIRONMENT
}

\author{
Alexander S. Romanov \\ $\mathrm{PhD}$ in Philology, Doctoral Degree Candidate, \\ $32^{\text {nd }}$ English Language Department, \\ Military University, MOD \\ Moscow, Russia, Volochaevskaya str., bld. 3/4 \\ biyalka@mail.ru
}

The current study focuses on the interrelations between ethnos, culture, and language. The object of this research embraces stereotypical perceptions of the social institution of the armed forces, professionally specified constants and axiological dominants of the army subculture, as well as the speech portrait of the US Army GI reference image, which are widespread in the collective language consciousness of the American linguoculture. Whereas, the researched subject is the military toast regarded as a productive language mechanism for explicating ethnic stereotypes of the army subculture. Stereotypes are perceived as a significant part of the conceptual world picture of the military socio-professional group, and are inextricably linked with the spiritual heritage of the American linguoculture. Being an integral part of the army, idiom toasts perform the function of axiological retransmission, shaping and consolidating stereotypes of the collective consciousness. 
Романов А.С. Застольные благопожелания в контексте этнокультурной...

Toasts reflect the spiritual principles of the army subcultural tradition, moral and ethical norms, rules of verbal and non-verbal behavior of military men. Belonging to a wide array of artifacts embodied in the army idiom, military stereotypes reflect key values of the military environment, provide for a correct navigation in critical situations and assist making optimal decisions. The epideictic genre of toast, therefore, can be described as a stereotypogenic language tool designed for manifestation of the army subcultural values and its corporate ethics.

Keywords: US Armed Forces, military subculture, stereotypization, stereotype, linguistic means of explicating of ethnic stereotypes of the US Army, army toast

\section{References}

Aristotel'. (2000) Pojetika. Ritorika [Poetics. Rhetoric]. Saint Petersburg: Azbuka. 347 P. Print. (In Russian)

Ahmanova O.S. (1969) Slovar' lingvisticheskih terminov [Dictionary of Linguistis Terms]. Moscow: Sovetskaja jenciklopedija. 608 P. Print. (In Russian)

Karaulov Ju.N. (1986) Rol' precedentnyh tekstov v strukture i funkcionirovanii jazykovoj lichnosti [The role of Precedent Texts in the Structure and Functioning of the Language Person. Scientific Tradition and New Trends in Teaching the Russian Language and Literature. Reports of the Soviet delegation at the VI Congress MAPRYAL], 105126.Moscow: Russkij jazyk. Print. (In Russian)

Slyshkin G.G. Lingvokul'turnye koncepty precedentnyh tekstov [Lingvocultutal Concepts of Precedent Textx]. Moscow: Academic. 141 P. Print. (In Russian)

Men'shenina S.V. (2005) Zhanry rechej. Klassifikacija jepidejkticheskoj rechi / S.V. Men'shenina [Speech Genres]. Vestnik Juzhno-Ural'skogo gosudarstvennogo universiteta. Serija: Social'no-gumanitarnye nauki [Letters of South Ural State University]: 7 (47): 181-185.Cheljabinsk: JuUrGU. Print. (In Russian)

Moshhanskaja E.Ju., Savchuk A.S. (2011) Tost kak ustno-rechevoj diskurs [Toast as Speech Discourse] Vestnik Nizhegorodskogo gosudarstvennogo lingvisticheskogo universiteta im. N.A. Dobroljubova [Letters of Nizhni Novgorod Linguistic State University]16: 80-90. Nizhnij Novgorod: FGBOU VPO NGLU. Print. (In Russian)

Kouplend N. (1991) Psihologija i soldat [Psychology of Soldier] trans. from English by Sapronova, A.T., Katerinicha,V.M., $2^{\text {nd }}$ edition. Moscow: Voenizdat. 96 P. Print. (In Russian)

Kul'tura russkoj rechi: jenciklopedicheskij slovar'-spravochnik (2003) [Russian Speech Culture] ed. by Ivanova, L.Ju., Skovorodnikova, A.P., Shirjaeva, E.N. i dr. Moscow: Flinta; Nauka. 840 P. Print. (In Russian)

Matveeva T.V. (2010) Polnyj slovar' lingvisticheskih terminov [Full Dictionary of Linguistic Terms]. Rostov-on-Don: Feniks. 562 P. Print. (In Russian)

Romanov A.S. (2015) Jazykovye sredstva jeksplikacii jetnicheskih stereotipov v kartine mira amerikanskih voennosluzhashhih: dis... kand. filol. nauk: 10.02.19 [Linguistic Means Explaining Ethnic Stereotypes of World Picture of American Military Men] Ph.D. Dissertation.195 P. Print. (In Russian)

Slovar' russkogo jazyka: v 4-h t. (1981) [Russian Language Dictionary] ed. by A. P. Evgen'eva. Moscow: Russkij jazyk, 1981. V. 1. A-J. 698 P. 1984. V. 4. S-Ja. 794 P. Print. (In Russian)

Shatalova S.V. (2009) Jepidejkticheskie zhanry rechi: avtoref. dis... kand. filol.

Вопросы психолингвистики 1 (35) 2018 
nauk. [Epideictic Speech Genres] Ph.D. Dissertation. 24 P. Print. (In Russian)

Ammer C. (1997) The American Heritage dictionary of idioms / Christine Ammer. - Houghton Mifflin Harcourt,1997. 1st ed. 736 P. Print.

Army.mil.som. URL: http://www.army.mil/values/ (retrieval date: 21.06.17).

Dining-In and Dining-Out Handbook. USAREC Pamphlet 600-15. Headquarters United States Army Recruiting Command. Kent.: Fort Knox, 1994. 9 p. [Jelektronnyj resurs]. - URL: http://img.slate.com/media/53/military\%20dining\%20handbook.pdf ( retrieval date 10.05.17). Web.

Etiquettescholar.com. URL: https://www.etiquettescholar.com/dining_etiquette/ toasting_etiquette/toasts_for_all_occassions/military_toasts.html (retrieval date 12.05.17). Web.

Guide to the Military Dining-in (revised 1999 edition). Cadet Hostess Office. Cullum Memorial Hall. N.Y.: West Point, 1999. 26p. URL: https://www.google.ru/url? $\mathrm{sa}=\mathrm{t} \& \mathrm{rct}=\mathrm{j} \& \mathrm{q}=\& \mathrm{esrc}=\mathrm{s} \&$ source $=$ web\& $\mathrm{cd}=1 \& \mathrm{ved}=0 \mathrm{ahUKEwiJIIX8s}$ _VAhXDYJoKH fmDbIQFggmMAA\&url=http $\% 3 \mathrm{~A} \% 2 \mathrm{~F} \% 2 \mathrm{Fwww}$.usma.edu $\% 2 \mathrm{Fdca} \% 2 \mathrm{FSiteAssets} \% 2 \mathrm{~F}$ SitePages\%2FMilitary\%2520Dining\%2FMilitaryDiningInGuide.doc\&usg=AFQjCNFwijcpiRNDdVci8FqXCgMDug5nQ (retrieval date 12.08.17). Web.

Militaryservicecompany.com. - URL: http://www.militaryservicecompany.com/ military-tradition/toasting-armed-forces/ (retrieval date: 19.08.17). Web.

Militarywives.com. URL: http://www.militarywives.com/index.php/protocolmainmenu-264/air-force-protocol-mainmenu-298/toasts-mainmenu-322 retrieval date: 21.07.17). Web.

Morris R. Toasting the Armed Forces / R. Morris. 2014 [Jelektronnyj resurs]. URL: http://www.militaryservicecompany.com/military-tradition/toasting-armed-forces/ (retrieval date: 13.08.17). Web.

Odierno R. This We'll Defend / R. Odierno. 2012. URL: http://armylive.dodlive. mil/index.php/2012/07/independence-day-2012/ (retrieval date 20.12.16). Web.

Samito C.G. Becoming American under fire: Irish Americans, African Americans and the politics of citizenship during the Civil War Era / C.G. Samito. N.Y.: Cornell University Press, 2009. 320 P. Print.

Supertrap.com [Jelektronnyj resurs]. URL: http://www.supertrap.com/ST Downloads_files/Army\%20Slang.pdf (retrieval date: 15.11.13). Web.

Vetfriends.com [Jelektronnyj resurs]. URL: http: //www.vetfriends.com/jokes/ index.cfm?startNum=50 (retrieval date: 14.03 .13 ). Web. 